\title{
The Perception of Doctor and Pharmacist in Interprofessional Collaborative in Pharmaceutical Care Services at General Hospital H. Adam Malik Medan
}

\author{
Riza Fahlevi Wakidi*', Adhisty Nurpermatasari ${ }^{1}$ \\ ${ }^{I}$ Departement of Pharmacy, Health Polytechnic Ministry of Health, Medan, North Sumatera, Indonesia.
}

\begin{abstract}
Collaboration is a complex process that requires planned knowledge sharing and be a joint responsibility to treat patients. The purpose of this study was to determine the perception of doctors and pharmacists in terms of the aspects of acceptance, expectations, and experience in collaborating on pharmaceutical care services on general hospital of H. Adam Malik Medan. This research is a survey research, located at general hospital of $\mathrm{H}$. Adam Malik Medan. The sample in this study were 50 doctors and 10 pharmacists at general hospital of $\mathrm{H}$. Adam Malik Medan. Data collection was carried out using a questionnaire. Analysis of the data used is descriptive analysis. The conclusion of this study is the perception of acceptance, current and future doctor's expectations of the role of pharmacists in collaborating on pharmaceutical care services is quite high, and perception of acceptance, pharmacist's current and future expectations of the role of pharmacists in collaborating on pharmaceutical care services are also high enough.
\end{abstract}

Keywords: collaboration, perception, pharmaceutical care services

\begin{abstract}
Abstrak. Kolaborasi merupakan proses komplek yang membutuhkan sharing pengetahuan yang direncanakan dan menjadi tanggung jawab bersama untuk merawat pasien. Tujuan penelitian ini adalah untuk mengetahui persepsi dokter dan apoteker yang ditinjau dari aspek penerimaan, harapan, dan pengalaman dalam berkolaborasi pada pelayanan asuhan kefarmasian di Rumah Sakit Umum Pusat H. Adam Malik Medan. Penelitian ini adalah penelitian survei, berlokasi di RSUP H. Adam Malik Medan. Sampel dalam penelitian ini adalah 50 dokter dan 10 apoteker di Rumah Sakit Umum Pusat H. Adam Malik Medan. Pengumpulan data dilakukan dengan menggunakan kuesioner. Analisa data yang digunakan adalah analisa deskriptif. Kesimpulan dari penelitian ini adalah persepsi penerimaan, harapan dokter saat ini dan dimasa yang akan datang terhadap peran apoteker dalam berkolaborasi pada pelayanan asuhan kefarmasian adalah cukup tinggi, dan persepsi penerimaan, harapan apoteker saat ini dan dimasa yang akan datang terhadap peran apoteker dalam berkolaborasi pada pelayanan asuhan kefarmasian juga cukup tinggi.
\end{abstract}

Kata kunci: kolaborasi, persepsi, pelayanan asuhan kefarmasian

Received 26 January 2020 | Revised 26 June 2020 | Accepted 28 July 2020.

\footnotetext{
*Corresponding author at: Departement of Pharmacy, Health Polytechnic Ministry of Health, Medan, North Sumatera, Indonesia

E-mail address: dz_fa03@yahoo.com
} 


\section{Introduction}

The implementation of pharmaceutical care proved to be slower than expected even though many pharmacists agreed to the concept [1]. Barriers to the application of pharmaceutical care can originate from within the pharmacist himself such as lack of communication skills, self confidence, and clinical skill. Moreover, obstacles also come from outside pharmacists such as the reluctance of other health professionals to collaborate with pharmacists [2]. To start a collaborative working relationship between the doctor and the pharmacist, it must be known in advance the doctor's perception of the role of the pharmacist in matters expected by the doctor from the role of the pharmacist. The existence of a collaborative working relationship between health workers, is expected to help patients so that the patient's quality of life improves. Collaborative pharmacy practice is defined as a clinical practice where pharmacists are able to work collaboratively with other health professionals in treating patients.

One of the underlying clinical pharmacy implementation in hospital health services in Indonesia is Regulation of the Minister of Health No. 58 year 2014 concerning pharmaceutical service standards in hospitals which states that pharmaceutical services in hospitals include the management of pharmaceutical preparations, medical devices and consumable medical materials and clinical pharmacy services as well as Implementation of Regulation of the Minister of Health No. 72 year 2016.

The good practice of collaboration among the healthcare professions is known as the Interprofessional Collaboration (IPC). Because it can synergize and streamline the care given to patients, IPC is important. The sustainability of IPC will be better if all health workers understand the roles, core competencies, basic language and mindset of other health workers and develop good attitudes and behavior [3].

The National Prescribing Service of Australia found that $6 \%$ of hospital cases were caused by drug side effects and high error rates during switching care. The source of the problem is poor collaboration between doctors and pharmacists. Poor collaboration is the most important factor in medication and medication errors. In the practice of collaboration among health workers, problems often occur such as an imbalance of authority, overlapping roles and organizational structures. These problems should be solved by implementing the components of good collaboration practices [4].

Collaboration is a complex process that requires planned knowledge sharing and is a shared responsibility to treat patients. Team work in equality is the basic essence of collaboration that we use to describe the relationship of pharmacists and doctors. Surely there are consequences behind 
the issue of equality in question. Equality is possible if the individuals involved feel valued and involved physically and intellectually when providing assistance to patients [5]. The question is whether collaboration between doctors and pharmacists has occurred properly. To answer the question above, the researcher is interested in researching about the perception of doctors and pharmacists in collaborating together in pharmaceutical services at general hospital of $\mathrm{H}$. Adam Malik Medan.

\section{Methods}

This study is a survey research with observational research, with cross sectional approach. Researchers in this study did not intervene/treat the research subjects but only made observations. The population in this study were all doctors and pharmacists at H. Adam Malik General Hospital Medan. The sample in this study were doctors and pharmacists at H. Adam Malik General Hospital Medan, with inclusion criteria that are those who are willing to be respondents. The research sample was taken using the non probability sampling method with snowball sampling technique. Data collection in this study was conducted by survey method. The instrument used to collect data in this study was a questionnaire with a Likert-type format measurement scale. In this study the measurement scale is divided into five namely strongly agree, agree, neutral, disagree and strongly disagree. The list of questions used in this study is divided into five sections namely individual characteristics of doctors and pharmacists, doctor's and pharmacist's current expectations, the actual experience of doctors and pharmacists, doctor's expectations for the role of pharmacists in the future.

The research conducted was non-experimental analyzed descriptively. In terms of data processing, this research is quantitative because the data obtained from this study will be processed with descriptive statistical analysis. This study is a cross sectional design where data collection is only done once. Based on the nature or place of the data obtained, this study uses a survey method with questionnaire instruments.

\section{Results and Discussion}

\subsection{Distribution of Doctor Respondent Characteristics}

Respondents used in this study were 50 doctors at the H. Adam Malik General Hospital Medan. Based on the characteristics of respondents obtained data on gender, age, length of work, doctor's knowledge of the concept of pharmaceutical care and the frequency of interactions with pharmacists are shown in Table1. 
Table 1. Description of the characteristics doctors at H. Adam Malik General Hospital Medan

\begin{tabular}{|c|c|c|c|}
\hline Description & Category & $\begin{array}{l}\text { Frequency } \\
\text { (Person) }\end{array}$ & $\begin{array}{c}\text { Percentage } \\
(\%)\end{array}$ \\
\hline \multirow{2}{*}{ Gender } & Male & 34 & 68 \\
\hline & Female & 16 & 32 \\
\hline \multirow{4}{*}{ Age } & $<30$ years & 9 & 18 \\
\hline & $30-40$ years & 13 & 26 \\
\hline & $40-50$ years & 16 & 32 \\
\hline & $>50$ years & 12 & 24 \\
\hline \multirow{4}{*}{ Length of work } & $<5$ years & 13 & 26 \\
\hline & $5-10$ years & 7 & 14 \\
\hline & $10-15$ years & 14 & 28 \\
\hline & $>15$ years & 16 & 32 \\
\hline \multirow{2}{*}{$\begin{array}{l}\text { Ever heard of the concept } \\
\text { Pharmaceutical care }\end{array}$} & Ever & 37 & 74 \\
\hline & Never & 13 & 26 \\
\hline \multirow{5}{*}{$\begin{array}{l}\text { Frequency of interaction } \\
\text { with the Pharmacist }\end{array}$} & Never & 2 & 4 \\
\hline & Rarely & 4 & 8 \\
\hline & $1-3 \times$ a week & 11 & 22 \\
\hline & $4-5 x$ a week & 25 & 50 \\
\hline & $>5 \times$ a week & 8 & 16 \\
\hline
\end{tabular}

Based on Table. 1 shows a description of the characteristics of doctors in H. Adam Malik General Hospital Medan in answering statements regarding the problems in this study.

\subsection{Distribution of Pharmacist Respondent Characteristics}

Respondents used in this study were 50 pharmacists at the H. Adam Malik General Hospital Medan. Based on the characteristics of respondents obtained data on gender, age, length of work, pharmacist's knowledge of the concept of pharmaceutical care and the frequency of interactions with pharmacists are shown in Table 2.

Table 2. Description of the characteristics the pharmacists at H. Adam Malik General Hospital Medan

\begin{tabular}{clcc}
\hline \multirow{2}{*}{ Description } & \multicolumn{1}{c}{ Category } & $\begin{array}{c}\text { Frequency } \\
\text { (Person) }\end{array}$ & $\begin{array}{c}\text { Percentage } \\
(\%)\end{array}$ \\
\hline \multirow{2}{*}{ Gender } & Male & 6 & 60 \\
& Female & 4 & 40 \\
< 30 years & 1 & 10 \\
Age & 30-40 years & 3 & 30 \\
& 40-50 years & 4 & 40 \\
Length of work & >50 years & 2 & 20 \\
& <5 years & 2 & 20 \\
& 5-10 years & 3 & 30 \\
& 10-15 years & 3 & 30
\end{tabular}




\begin{tabular}{clcc} 
& $>15$ years & 2 & 20 \\
Ever heard of the concept & Ever & 10 & 100 \\
Pharmaceutical care & Never & - & - \\
& Never & 1 & 10 \\
Frequency of interaction & Rarely & 2 & 20 \\
with the Pharmacist & $1-3$ x a week & 1 & 10 \\
& $4-5$ x a week & 4 & 40 \\
& $>5$ x a week & 2 & 20 \\
\hline
\end{tabular}

Based on Table 2 shows a description of the characteristics of pharmacists in RSUP H. Adam Malik Medan in answering statements regarding the problems in this study.

\subsection{Distribution of Doctor Respondent's Answers}

Distribution of respondents' answers to get a more detailed picture of the results of research on the current expectations of doctors regarding the role of pharmacists in providing pharmaceutical services shown in table 3 .

Table 3. Distribution of Doctor Respondent's Answers

\begin{tabular}{|c|c|c|c|}
\hline \multirow[b]{2}{*}{ Descriptions } & \multicolumn{2}{|c|}{ Average Score } & \multirow[b]{2}{*}{ Note } \\
\hline & Mean (SD) & $\begin{array}{c}\text { Achievement of } \\
\text { Respondents Rate }(\%)\end{array}$ & \\
\hline $\begin{array}{c}\text { Current Doctors' } \\
\text { Expectations of the Role } \\
\text { of Pharmacists in } \\
\text { Pharmaceutical Care } \\
\text { Services }\end{array}$ & 3.74 & 41.50 & High enough \\
\hline $\begin{array}{l}\text { Actual Experience of } \\
\text { Doctors and Pharmacists } \\
\text { in Pharmaceutical } \\
\text { Services }\end{array}$ & 3.53 & 49.02 & High enough \\
\hline $\begin{array}{l}\text { Doctor's Expectation on } \\
\text { the Role of Pharmacists in } \\
\text { the Future in } \\
\text { Pharmaceutical Services }\end{array}$ & 3.79 & 48.38 & High enough \\
\hline
\end{tabular}

\subsection{Distribution of Phamacists Respondent's Answers}

Distribution of respondents' answers to get a more detailed picture of the results of research on the current expectations of pharmacists regarding the role of pharmacists in providing pharmaceutical services shown in table 4 . 
Table 4. Distribution of Phamacists Respondent's Answers

\begin{tabular}{|c|c|c|c|}
\hline \multirow[b]{2}{*}{ Descriptions } & \multicolumn{2}{|c|}{ Average Score } & \multirow[b]{2}{*}{ Note } \\
\hline & Mean (SD) & $\begin{array}{c}\text { Achievement of } \\
\text { Respondents Rate }(\%)\end{array}$ & \\
\hline $\begin{array}{l}\text { Pharmacist's current } \\
\text { expectations of the } \\
\text { role of Pharmacists in } \\
\text { pharmaceutical } \\
\text { services }\end{array}$ & 4.24 & 34.81 & Low \\
\hline $\begin{array}{l}\text { Actual Experience of } \\
\text { Pharmacists with } \\
\text { Doctors in } \\
\text { Pharmaceutical } \\
\text { Services }\end{array}$ & 3.91 & 42.34 & Enough \\
\hline $\begin{array}{c}\text { Pharmacists' } \\
\text { Expectations for the } \\
\text { Future Role of } \\
\text { Pharmacists in } \\
\text { Pharmaceutical } \\
\text { Services }\end{array}$ & 4.00 & 42.31 & High enough \\
\hline $\begin{array}{l}\text { The results showed th } \\
\text { Pharmaceutical Service } \\
\text { Respondents Rate of } 41 \\
\text { patients about the dise } \\
\text { disease. The doctor also } \\
\text { medication is refilled, o } \\
\text { find out the specific } \\
\text { indication. Pharmacists } \\
\text { of health professionals } \\
\text { great opportunity to inte } \\
\text { [6]. The health service } \\
\text { documents by the gove } \\
\text { 2009. }\end{array}$ & $\begin{array}{l}\text { current Doc } \\
\text { high enough } \\
\text { The expectat } \\
\text { on-pharmaco } \\
\text { that Pharmac } \\
\text { and help imp } \\
\text { ions of each } \\
\text { an important } r \\
\text { ire in the van } \\
\text { ith patients a } \\
\text { tharmacists is }\end{array}$ & $\begin{array}{l}\text { expectation against the } \\
\text { ory with a mean of } 3.7 \\
\text { Doctor that Pharmacists } \\
\text { therapy and lifestyle } \\
\text { in take reasonable steps to } \\
\text { atient compliance with tre } \\
\text { prescribed when the de } \\
\text { the implementation of dru } \\
\text { of providing health servi } \\
\text { lore information related } t \\
\text { ag stronger with the issu } \\
\text { ent of Health, Governmer }\end{array}$ & $\begin{array}{l}\text { of Pharmacists in } \\
\text { d Achievement of } \\
\text { ive an education to } \\
\text { es related to their } \\
\text { re that the patient's } \\
\text { nt. Pharmacists can } \\
\text { as more than one } \\
\text { onciliation. As part } \\
\text { harmacists have a } \\
\text { history of drug use } \\
\text { of several legality } \\
\text { gulations No. } 51 \text { of }\end{array}$ \\
\hline
\end{tabular}

The actual experience of doctors and pharmacists in pharmaceutical services is high enough too with a mean of 3.53 and Achievement of Respondents Rate of $49.02 \%$. Based on the experience of the doctor Pharmacists often ask the doctor to clarify the purpose of patient's treatment, Pharmacists are a reliable source of general drug information (i.e drug facts that can be found in 
standard references) [7]. The existence of a collaborative working relationship between healthcare professional, is expected to help patients so that the patient's quality of life improves. Collaborative pharmacy practice is defined as a clinical practice in which pharmacists are able to work collaboratively with other health professionals in treating patients [8].

\section{Conclusion}

The conclusion of this study is the perception of acceptance, current and future doctor's expectations of the role of pharmacists in collaborating on pharmaceutical care services is high enough, and perceptions of acceptance, pharmacists' current and future expectations of the role of pharmacists in collaborating with the service pharmaceutical care is also high enough.

\section{Acknowledgment}

The authors thanks to Departement of Pharmacy, Health Polytechnic Ministry of Health, Medan, North Sumatera, Indonesia for supporting this research.

\section{REFERENCES}

[1] M. A. Gastelurrutia, F.F. Llimós, P.G. Delgado, P. Gastelurrutia, J. Maria, S. I. Benrimoj, "Barriers and Facilitators to the Dissemination and Implementation of Cognitive Services in Spanish Community Pharmacies", Journal of Pharmacy Practice, Vol. 3, No. 2, PP. 65-77, July 2005.

[2] M.R. Rokhman, K.N. Utami, N.A. Dianastuti, "Barrier, Facilitator, and Pharmacist Attitude Modeling to Implement Pharmaceutical Care in the Yogyakarta Regional Community Pharmacy", Report of Research, University of Gadjah Mada, Yogyakarta, 2012.

[3] D. V. Kelly, L. Bishop, S. Young, J. Hawboldt, L. Phillips, T.M. Keough, "Pharmacist and Physician Views on Collaborative Practice: Findings from the Community Pharmaceutical Care Project", Canadian Pharmacists Journal, Vol. 146, No. 4, pp. 218-26, July 2013.

[4] E.F. Abu-Gharbieh, H.S. Ali, "Professional Practice and Prescription Towards Rational Use of Medicine According to WHO Metodology in Uni Emirates Arab", Pharmacy Practice, Vol. 8, No. 1, pp. 70-76, Januari 2010.

[5] M. Aslam, C.K. Tan, A. Prayitno, Clinical Pharmacy: Towards Rational Medicine and the Choice of Patient, Elex Media Komputindo, Jakarta, p. 6, 2003.

[6] C.D. Hepler, "Clinical Pharmacy, Pharmaceutical Care, And The Quality Of Drug Therapy", Journal of Pharmacotherapy, Vol. 24, No. 11, pp. 1491-1498, November 2004.

[7] S.R. Prima, A.Z. Adnan, R. Rahim, "Doctor's Perception About the Role of Pharmacists in Pharmaceutical Services at the Central General Hospital (RSUP) Dr. M. Djamil Padang", Journal of Social Clinical Pharmacy Indonesia, Vol. 1, No. 2, September 2016.

[8] Ikawati, Zulies, "The Pattern of Collaboration Between Pharmacists and Doctors in Health Services", Journal of Health Services Management, Vol. 6, No. 3, pp. 117-124, 2003. 